\title{
Adoption of Whole Group Strategy on Standard Seven Learners' Achievement in English Composition Writing in Public Primary Schools in Kisumu County, Kenya
}

\author{
Kamau Wambui Hellen Odundo Amollo Paul Inyega Nasimiyu Hellen \\ Department of Educational Communication \& Technology, University of Nairobi, Kenya
}

\begin{abstract}
Adaptation of whole group technique in teaching standard seven learners in English composition writing offers an opportunity for collaboration for nurturing effective communication skills. Appropriate adoption of brain wave, brain storming, pie storm and brain writing techniques influence learner's achievement in composition writing skills. Whole group promotes critical thinking, writing skills, communication, and collaboration the group discussion translating to sharing and weaving ideals enhances the ability to boost learner's achievement in composition writing. Absence of the implementation causes double tragedy to the learners and facilitators. The study objective was to determine influence of whole class group strategy on learners' achievement in composition writing skills in public primary schools in Kisumu County. Drawing from critical thinking skills the study adopted non-equivalent control group with pre and post -test groups research design. Questionnaire, observation schedules and check lists were used to collect data tired to descriptive statistics.The findings indicated that brain writing strategy was moderately used $(\mathrm{m}=3.40 \mathrm{SD}$ of 1.269$)$, pie storm teaching technique is highly used $(\mathrm{m}=3.733$ and $\mathrm{SD}$ of 1.796$)$, and brain wave and brain writing strategy relatively contribute to learners' composition writing skills. The computed $z$ values for whole class group strategy elements revealed a $z$-statistic value higher than the $\mathrm{z}$ - Critical value and P-value less than 0.05 . Thus, the study rejected the Null hypotheses as there was a statistically significant relationship between: whole group strategy and learners' achievement in composition writing skills in public primary schools in Kisumu County. The study recommends for policy the use of inquiring-based learning in order to provoke critical-thinking in learners to cub negative attitude of embracing change of teaching for life and not for examinations. A research on inferential statistics, especially multiple regression analysis, whole group style to be trained to facilitators to impact on the learners achievement in composition writing
\end{abstract}

Keywords: Whole group Brain storming; Brain wave; Brain writing; Composition writing; Learners achievements; Pie storm;

DOI: $10.7176 / \mathrm{JEP} / 10-3-10$

\section{Introduction}

Whole group strategy offers innovations, imaginative powers which assist learners to explore new style of writing skills Mwangi,( 2016) affirmed that teaching methods are appropriately structured in teaching drama, however this can facilitates masterly of concepts appropriately to boost composition writing. As Current constituted teacher training over looks for promoting mastery of composition writing .In addition, advances the whole group style indicating newer perspectives on teaching and learning composition writing for improved learners achievement. This includes an educational approach that aims and fosters the holistic learning of a person. New trends of education is vital in order to fit into the $21^{\text {st }}$ Century ways of delivering content to learners Main method of teaching helps the teacher to reach out to learners in order to boost competency .there is need to emphases whole group technique in improving learners competence in English composition writing ((Mundu, 2017). Thus onset of appropriate thought of adequate methodology is important for teaching and learning composition writing. ( Mwanda, 2016)

Oduo, $\mathrm{O}$ and Owaba, $\mathrm{O}(2017)$ argued that brain writing facilitates individual thinking alone for 5minutes recording 3 ideals, which inspires others to generate ideals in a short time. However the learners who are hyper active are slowed down to allow the rest of the learners an opportunity to participate without blocking, intimidation and pressure to facilitate positive impact on composition writing. Further Brain-writing is an alternative method to brainstorming that tries to encourage a more uniform participation within a group. Like brainstorming, it is designed to generate lots and lots of ideas in a short amount of time (Marcela Litcanua , Octavian Prosteana, Cosmin Orosa, Alin Vasile and Mnerieb 2014 ) .Whole group strategy gives learners appropriate opportunities to articulate ideas liberally about the content topic given by the educator. In whole group strategy, Valve creation is embraced while learners share, discuss, critique each other's work and listening to group presentation. However when whole group is not embraced in the teaching and learning composition writing is inadequately understood .In supports of this position Hun and Chik( 2018) opionated that Whole group strategy offers opportunity to attend to individual differences however minimal attention maybe given to learners who require close supervision. In addition Barr (2016), in a vivid study of reading skills for secondary school 
education in Minnesota Public schools summed up that, majority of learners in Minnesota struggle in the area of reading comprehension. This enhances the writing of composition in order to improve the learner's achievement.

Further still Almutairi (2015) asserted that there are statistical significant differences at the levels of (a-0.05) between the experimental group and the control group in total score and the sub score of the creative thinking in the favour of the experimental group indicating the effectiveness of using brainstorming strategy in developing creative thinking skills. In addition Alshammari (2015) carried a study on Effectiveness of using Brain storming strategy in developing creative thinking skills .Based on the study results showed statistically significant differences in the achievement and total achievement in favour of the experimental group that he studied using the brainstorming as an instructional strategy in education and that the elementary teachers should use Brainstorming in daily lesson plans. However in an effort to address the gap Kentucky (2015) asserted that a statistically significant correlation between intercultural sensitivity and foreign languages teaching motivation using brainstorming method. This study examined adoption of brainwave, brain storming ,pie storming and brain writing influence on composition writing on standard seven learners achievement in English composition writing in public primary schools in Kisumu County, Kenya

\subsection{Brain Wave style and composition writing}

Whole group style prompts collaboration, communication, competency based and hands on approaches .This approach has different sub-dimensions among them is brain wave approach. Brain wave group is an activity among learners during class sessions reflecting on team work and interpersonal relationships. According to Westbye (2012) in pie storm, Kiendinger (2011) in brain wave and Aritini (2011) in brain storm asserted that whole class technique in brainstorming enhances construction of paragraphs and positive correlations between brains based learning strategies and expected learner's achievements. In support of these contestation. Lenn(2006) in silent reflection, Martal (2014) in three minutes each way, Grum(2007) in Buzz group asserted that small group technique could improve the learners' active participation and reading comprehension. this is in conquers with Martini (2011) that while doing a research on application of brainstorming teaching technique it improves writing skills of the eighth-grade students of SMPN 2 SUKAWATI in academic year 2013 -2014. However Martin (2011) found out that the strategy did not only focus on the improvement of subject's ability but also the subject's responses after having the lessons. In this regard teaching and learning process, focused on brainstorming technique was implemented in the classroom, which in turn improved learners' active participation in construction of paragraphs. In addition Martin (2011) found brain wave lacking as it adapted how to enrich the understanding of brainstorming technique and modification in order to obtain better results of conducting classroom action research that investigates writing skills. Drawing from this premise this study sought to determine effectiveness of brain wave group on composition writing among standard seven learners achievement in English composition writing in public primary schools in Kisumu County, Kenya.

\subsection{Brain storm approach and composition writing}

Whole group approach offers learners opportunities of sharing, critiquing each other's ideals, listening skills and critical thinking enhanced. Brainstorm approach is a quick, gullible free-association on paper, writing columns of single words or very short phrases. According to Friedlander (2013) brain storming idea is to get our brain spinning or freewheeling, just discarding stuff out without any concern about its significance, correctness, worth or reason. This implies learners naturally seek to control what we write but gaining the recreation to brainstorm in this manner sometimes takes a little practice. In instances where brain storming strategy is effective adoption are that it can begin immediately, move rapidly, and often produce unexpected ideas or angles. For effective writing skills to thrive, learners need to work in groups that are actively involved in creating webs that weave together ideas. These promote exposures to own and others experiences embracing different valves and powerful narrations. . However brain storming requires a lot of planning, space and learning resources to benefit learners .Ahmed (2014) further states that when teachers are effective on practice, , brainstorming becomes a rapid, low-stress technique, so an ineffective session is not very expensive in time or attempt. According to Sabarun(2009) studied on effectiveness of using brainstorming technique in writing paragraphs across different levels of achievement at the second semester English department students of Palangka Raya state Islamic institute..Findings indicated the effectiveness of using brainstorming clustering technique on the quality of composition written by experimental group of bright and low students.. Further it revealed that at the $5 \%$ and $1 \%$ of significant level, there was a very statistically significant difference on students' writing achievement both for the bright and poor students between the students who wrote a time order paragraph using brainstorming technique and those who wrote a time order paragraph without using brainstorming technique. This study sought to determine effectiveness of brain wave group on composition writing among standard seven learners achievement in English composition writing in public primary schools in Kisumu County, Kenya 


\subsection{Pie Storm strategy and composition writing}

Whole group has been globally utilized by facilitators to enhance writing composition. Learners are given the content gradually until concepts is understood. Team work is created ,valves instilled in the process of teaching and learning. Pie storm group gives learners to take full ownership of the learning process. It is an inquiring -based learning. Critical thinking, collaboration, working together, innovation and resilience is evident in the pie storming strategy. Teacher takes the role of a facilitator meaning leading the teaching and learning process. The emphasis is all individual learners understand and internalise the concepts before moving to the next item per the objectives set. (Hatties's 2009). Westby (2012) conducted a case study to investigate second language teaching methods in two different countries. The result of the study leads to the conclusion that the Norwegian school might benefit from trying a teaching method more similar to the one used in American schools. In cases where in pie storm is adopted by teachers learners benefit in the mastery of content is delivered adequately. However, where pie storm is not implemented the syllabus is rushed without evaluation of concepts being understood properly Hatties (2009) found a miss- match where teachers at the control of the class demonstrate a challenging, carefully structure pace ,not letting learners fall behind as they try to figure it out for themselves. This study seeks to establish out, if Pie Storm is effective in teaching composition writing skill.

\subsection{Brain writing method and composition writing}

Whole group facilitates fun in learning which offers real opportunity to boost the writing compositions . This improves the target set. to boost the writing compositions ...In Brain writing strategy, learners are divided into groups provided for a writing material to put findings and time is allocated to them and timed for appropriateness, exchange is done by letting the next participant write something. The process goes on until it is completed. Brain writing is known as 6-3-5 to indicate the six learners in each group, five minutes taken by each and three ideals from every participant. Rhonda's (2011), in the study, Brain-based learning and its effects on reading outcome in elementary aged students, found out that, there was a constructive correlation among brain based knowledge strategies and expected learners attainment for these learners. A constant creative writing review can additionally discover the potential of brain study or how it links to learning. To achieve this, .Rhondas (2011) suggested that educators should continue to learn the general structures and functions of the brain, and gain more skills in implementing the technique of brain based learning in classroom .Rhondas( 2011)Pedagogy follows the test scores accurately represent what a child understands rather than what a child can reiterate.

Brain writing method carters for individuals who are not good in working under pressure and easily intimidated by learners who dominates the group. Odu.O,and Owaba ,O (2017) states that, in order to achieve the desired outcome of brain writing technique, clearly formulated ideas should be avoided so that participants can be creative. Because it runs quietly, some participants can concentrate better, which leads to a greater flow of ideas. This study seeks to examine the effectiveness of brain writing

Table 1. KCPE Mean Scores in English Language and Composition for Kisumu County Between 2014 to 2017

\begin{tabular}{|l|l|l|l|l|l|}
\hline \multirow{2}{*}{ Category } & \multicolumn{4}{|l|}{ Mean Score Performance } \\
\cline { 2 - 6 } & 2013 & 2014 & 2015 & 2016 & 2017 \\
\hline Language & $\mathbf{5 3 . 0 6}$ & $\mathbf{4 7 . 6 2}$ & $\mathbf{4 9 . 9 8}$ & $\mathbf{5 0 . 5 2}$ & $\mathbf{4 7 . 6 2}$ \\
\hline Composition & $\mathbf{4 1 . 9 0}$ & $\mathbf{4 1 . 4 5}$ & $\mathbf{4 1 . 3 8}$ & $\mathbf{4 0 . 2 5}$ & $\mathbf{3 9 . 6 0}$ \\
\hline
\end{tabular}

Source: The Kenya National Examination Council (2017).

\section{Statement of the Problem}

The Kenya National Examination Council (KNEC) has shown Primary schools learners have over the years performed poorly as indicated in the (KNEC Examination Report 2013-2017 demonstrated on the table above. Therefore, the delivery of the curriculum, monitoring and examination needs to be looked into to understand exactly where the gap is. This study has observed that the approaches taken by the teachers to deliver in Kisumu County have generally contributed to the overall results in National examinations (field observation). This study suggests that teachers of English while handling composition writing have to embrace different methods to use when teaching writing skills.

The Kenyan primary syllabus has emphasized on the resources, pedagogy of handling each component that translate to the overall performance of English language. The table 1 has shown that the grammar is better performed then the composition writing skills. Both have to be handled well since they both add up to the final grade for English as a whole paper. This is wanting since all instruction and assessment is done through the language despite its poor performance expect Kiswahili which performance well in insha writing than sarufi as evidence stipulated in (the KNEC) Examination Report 2013 -2017.

The new curriculum (CBC) has a lot of emphasis on Literacy activities especially to address the four skills which are very vital in the overall performance of English language. The brain storming technique has not been elaborated and comprehensively be looked at as a teaching strategy that can enhance critical thinking ,idea 
generation to boost the writing skills by the stalk holders ,the Ministry of Higher Education and Science and technology, The Kenya institute of curriculum development. Therefore, this study provides information on the influence of brain storming technique on standard seven learner's achievement in English composition writing in public primary schools in Kisumu County, Kenya. This study has demonstrated the need and urgency of its adoption and implementation.

\section{Purpose and Objectives}

The study purposed to determine teachers' influence of brainstorming techniques in composition writing skills of English language among standard seven learners. The objective was to examine influence of brave wave, brain storming, pie storm and brain writing of whole class technique on learners' achievement in composition writing skills in public primary schools in Kisumu County.

\section{Theoretical Perspectives}

Watson-Glaser's theory is to develop the mindset related to the learning system in attempt to enhance critical thinking ability. The characteristic used in measuring this ability was Watson-Glaser's critical thinking skill. Watson-Glaser critical thinking focuses on the relationship between rational thought and the process of education. The competencies measured by Watson-Glaser in developing critical thinking skills were Recognizing Assumptions, Evaluating Arguments, and Drawing Conclusions. This concept was expected to be used in the developing and improving individual's learners as well as achievements and also in understanding learners' both in school and outside the school

\section{Conceptual Frame Work}

According to Orodho, J. Nzabaliwa, W. Odundo, P. Waweru, P. Ndayambaje, I. (2016 ) a conceptual framework is a model of representation where a researcher conceptualizes or represents the relationships between variables in the study and shows the relationship graphically or diagrammatically. The independent variables are brainstorming techniques in composition writing which are brain wave, brain storming, brain writing and pie storming.

The dependent variable is the pupils' achievement and it's indicated by improved classroom participation, personalized learning and, active learning, improved thinking skills, improved writing skills, good usage of vocabulary and good sentence construction. This interplay between the independent and dependent variables is extraneously influenced by various factors such as: background knowledge, linguistic knowledge, and training of the teachers. The inter relationship among variables are conceptualized as illustrated in Figure 2.1. Brain storming technique is perceived to be a strong technique in influencing and strengthening learner's achievement
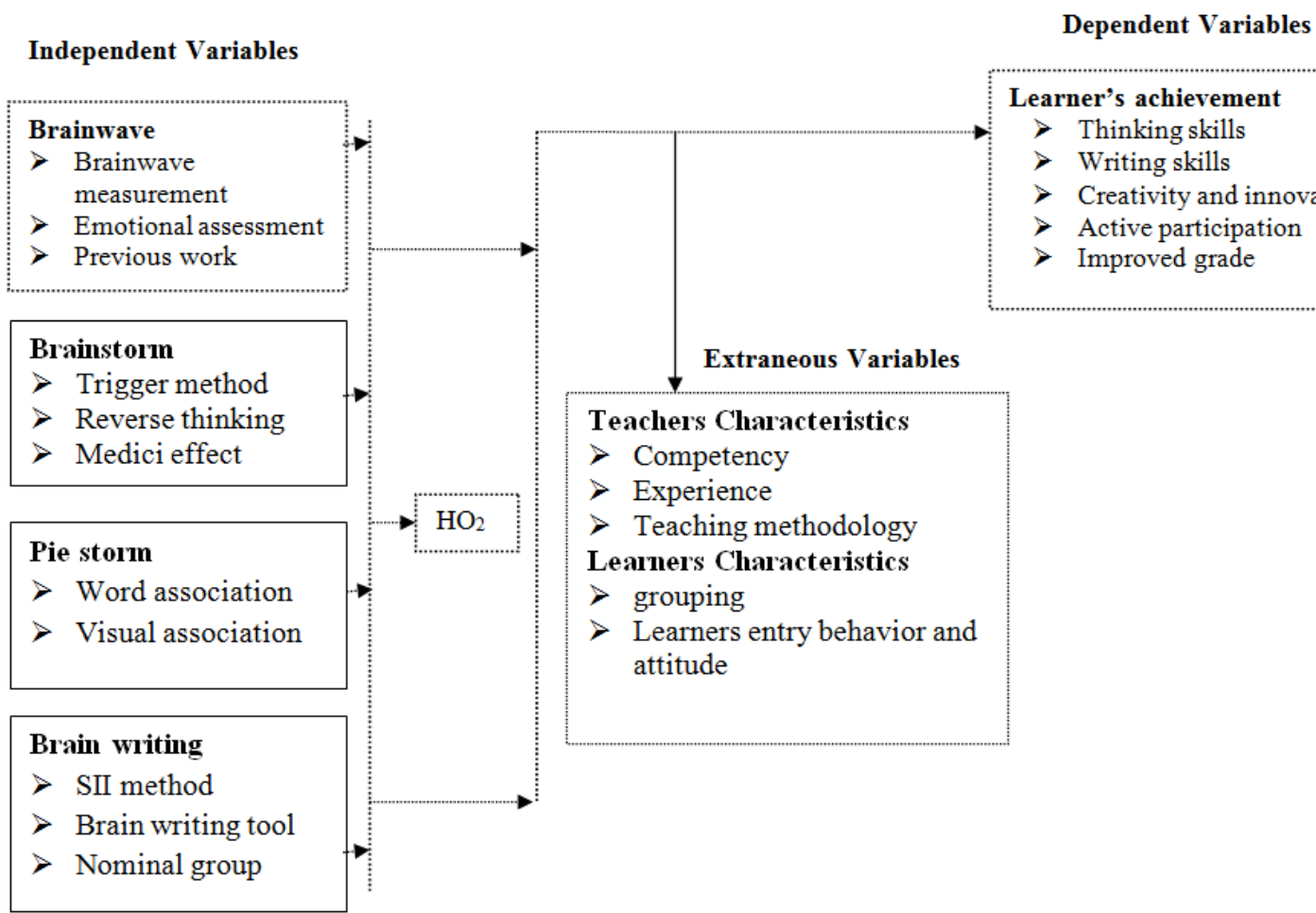

Learner's achievement

$>$ Thinking skills

$>$ Writing skills

$>$ Creativity and innovation

$>$ Active participation

$>$ Improved grade

Brainstorm

$>$ Trigger method

Reverse thinking

$>$ Medici effect

Pie storm

$>$ Word association

Visual association

Brain writing

$>$ SII method

Brain writing tool

Nominal group 


\section{METHODOLOGY}

The study adopted a quasi experiment of non-equivalent control group with pre and post-test research design which manipulated whole group group strategy.. Cohen, Manion and Morrison (2007) assert that non-equivalent control group design is commonly used in education research where participants have homogenous characteristics and in a class within a class where learners are naturally organized in groups. The design is ideal in classroom experiments when experimental and control groups are such naturally assembled groups as intact classes, which may be similar. The study comprised of 6 head teachers, 6 teachers of English, 280 learners. Data were collected via questionnaires, observation schedules, and check list. Whole group learning brain is moderately used $\mathrm{m}=3.40$ with $\mathrm{SD}$ of 1.269 , pie storm strategy is highly used $\mathrm{m}=3.733$ and $\mathrm{SD}$ of 1.796 , brainwave and brain writing strategy relatively contributes to learners composition writing.

\section{Findings and Discussions}

The study sought to examine influence of whole group technique on learners' achievement in composition writing skills. The questions for this analysis were extracted from teachers of English questionnaire part $\mathrm{F}$ (questions 1-9) and learners questionnaire part F (questions 1-9). The hypothesis tested under this objective was, $\mathrm{HO}_{2}$ (There is no statistically significant differences between whole class technique and learners' achievement in composition writing skills in public primary schools in Kisumu County). The objective was analysed on two stages using likert scale questions. Results are presented and discussed in 2, 3, 4, 5, 6, 7 .

\section{Use of Whole Class Technique}

The study analysis sought to determine how often teachers of English embrace whole class technique learning strategies in teaching composition writing in public schools in Kisumu County. Teachers of English were asked to rate their agreement on a four point likert scale of 1-4, with 1 denoting Never (N), 2 denoting Seldom (S), 3 denoting Some of the Time (SOT) and 4 denoting Most of the time (MOT).

\subsection{Frequency of Brain Wave Strategy}

The study sought to establish out how often teachers of English employed brain wave strategy while teaching English composition. Findings are presented in Table 2.

Table 2: Use of Brain Wave Strategy

\begin{tabular}{lll}
\hline Response Category & Frequency & Percent \\
\hline Most of the time & 1 & 16.67 \\
Some of the time & 3 & 50.00 \\
Seldom & 1 & 16.67 \\
Never & 1 & 16.66 \\
\hline Total & 6 & 100.00 \\
\hline
\end{tabular}

Analysis from Table 2 revealed that $1(16.67 \%)$ teacher of English most of the time used brain wave strategy in teaching composition, $3(50.00 \%)$ responded that they some of the time use brain wave strategy in teaching English composition writing, $1(16.67 \%)$ responded that he seldom uses the technique and $1(16.66 \%)$ teacher of English responded never to have used brain wave strategy. Mean and standard deviation rating for use of brain wave strategy revealed $\mathrm{M}=2.267$ and $\mathrm{SD}=1.960$. These findings imply that brain wave strategy is some of the time used in teaching composition writing in public primary schools in Kisumu County.

\subsection{Frequency of Brain Writing Strategy}

The analysis sought to determine how often teachers of English use brain writing in teaching composition writing in public primary schools. The results are shown in Table 3

Table 3: Use of Brain Writing Strategy

\begin{tabular}{lll}
\hline Response Category & Frequency & Percent \\
\hline Most of the time & 4 & 66.67 \\
Some of the time & 1 & 16.67 \\
Seldom & 1 & 16.66 \\
Never & 0 & 0.00 \\
\hline Total & $\mathbf{6}$ & $\mathbf{1 0 0 . 0 0}$ \\
\hline
\end{tabular}

Finding from Table 3 revealed that $4(66.67 \%)$ teachers of English use brain writing strategy most of the time as they teach composition writing, $1(16.67 \%)$ teacher uses brain writing strategy some of the time in teaching composition writing, and $1(16.67 \%)$ teacher seldom uses brain writing strategy. Mean and standard deviation rating for use of free writing strategy revealed $\mathrm{M}=3.50$ and $\mathrm{SD}=1.269$. These findings reveal that brain writing strategy is some of the time used in teaching composition writing in public primary schools in Kisumu County. This finding corroborates with Artini (2011) whose study on the "application of brainstorming teaching technique to improve writing skill of the eighth-grade students of SMPN 2 SUKAWATI in academic year 2013 2014" reported poor to moderated focus on the brain writing strategy and this he concluded to hinder students' 
ability to improve in subject and performance.

\section{7 .3 Use Pie Storm Strategy Occurrence}

The analysis sought to determine how often teachers of English use pie storm strategy in teaching composition writing in public primary schools. The results are shown in Table 4.

Westby (2012) conducted a case study to investigate second language teaching methods in two different countries. The result of the study leads to the conclusion that the Norwegian school might benefit from trying a teaching method more similar to the one used in American schools. Analysis inquired how often teachers of English in public primary schools use pie storm learning strategy in teaching English composition writing. Findings are presented in Table 4.

Table 4: Use of Pie Storm Strategy

\begin{tabular}{lll}
\hline Response Category & Frequency & Percent \\
\hline Most of the time & 2 & 33.33 \\
Some of the time & 2 & 33.33 \\
Seldom & 1 & 16.67 \\
Never & 1 & 16.67 \\
\hline Total & $\mathbf{6}$ & $\mathbf{1 0 0 . 0 0}$ \\
\hline
\end{tabular}

Table 3revealed that $2(33.33 \%)$ teachers of English responded that they most of the time use pie storm strategy in teaching English composition writing, 2 (33.33\%) teachers of English responded to some of the time use pie storm strategy, $1(16.67 \%)$ teacher responded to seldom use the strategy and $1(16.67 \%)$ teacher too responded to never use pie storm strategy in teaching composition writing. Mean and standard deviation rating of pie storm strategy use revealed $\mathrm{M}=2.833$ and $\mathrm{SD}=0.160$. This finding shows that pie storm strategy is some of the time used in teaching composition writing in public primary schools in Kisumu County. This finding concur with Alshammari (2015) who found significant influence of use of pie storm brainstorming learning techniques with students' performance in language teaching and acquisition of writing skills.

\section{Whole group Technique Influence on Learners Achievement}

The second phase of analysis sought to determine how whole class teaching technique of brainstorming influences learners' achievement. Learner respondents were asked to rate - on a five likert point scale (1=strongly disagree, 2=Disagree, $3=$ Indifferent, 4=Agrees and 5=Strongly Agrees) - the extent to which they agreed with the posed questions on indicators of whole class strategies. Results are discussed below.

\subsection{Brain Wave Strategy}

The study sought to establish how use of brain wave strategy influences learners achievement in composition writing. Three indicators were assessed and Findings are presented in Table 5.

Table 5: Brain Wave Strategy Influence on Learners Performance

\begin{tabular}{lll}
\hline Strategy Statements & Mean & Std. Dev \\
\hline I can identify similar incidences with my own experiences from the topic & 4.01 & 1.499 \\
I am able to identify and relate with the characters in the text am writing & 3.27 & 1.239 \\
\hline Average Score & $\mathbf{3 . 6 4}$ & $\mathbf{1 . 3 6 9}$ \\
\hline
\end{tabular}

Findings in Table 4 revealed learners agreed $(\mathrm{M}=4.01$ and $\mathrm{SD}=1.499)$ they can identify similar incidences with own experiences from the topic. Similarly, learners were indifferent $(M=3.27$ and $S D=1.239)$ whether they can identify and relate with the characters in the writing text. This findings show that learners are able to identify incidences with own experiences from the topic; however they cannot tell whether they can relate with characters in the writing text. The mean and standard deviation for brain wave strategy revealed $\mathrm{M}=3.64$ and $\mathrm{SD}=1.369$ which imply use of brain wave strategy strongly contributes to learners achievement in composition writing skills in public primary schools. This is in agreement with Rhondas (2011) whose study on "brain-based learning and its effects on reading outcome in elementary aged students" reported a positive correlation between brain wave based learning strategies and expected student achievement for these students.

\subsection{Brain Storming activities}

The analysis sought to examine influence of free writing indictors on learner's achievement in composition writing. Findings are shown Table 5.

Table 6 : Brain Storming Strategy Influence on Learners Achievement

\begin{tabular}{lll}
\hline Strategy Statements & Mean & Std. Dev \\
\hline I am able to identify the main ideas of the story. & 4.41 & 1.341 \\
I am able to identify the cause of the conflict/problem in the story. & 2.27 & 1.012 \\
\hline Average Score & $\mathbf{3 . 3 4}$ & $\mathbf{1 . 1 7 7}$ \\
\hline \multicolumn{1}{c}{ Findings shown in Table 5 revealed learners strongly agreed (M=4.41 and SD=1 341) they can identify the }
\end{tabular}


main ideas of the story. In addition, finding also revealed learners disagree $(\mathrm{M}=2.27$ and $\mathrm{SD}=1.012)$ they can identify the cause of conflict in the story. These findings imply learners can identify the main idea of the story when they write composition, but they cannot identify the causes of conflict or problems in the story. Since composition writing is majorly about story telling ability of the learners to identify the causes of conflict or problem in the study is paramount and allow learners to organize their writing script coherently. The mean and standard deviation finding for brain storming strategy gave a $\mathrm{M}=3.34$ and $\mathrm{SD}=1.177$ which imply that brain storming technique is a major contributor of excellent composition writing in public primary schools in Kisumu county. The finding could be a contributing factor to low performance of the subject. This finding corroborates with Almutairi (2015) study which reported a positive correlation between brain wave based learning strategies and expected student achievement for these students.

\subsection{Brain writing group work}

The present study analysis sought to determine out the influence of brain writing strategy on learners achievement in composition writing. Findings are shown Table .7

Table 7: Brain Writing Strategy Influence on Learners Achievement

\begin{tabular}{lll}
\hline Strategy Statements & Mean & Std. Dev \\
\hline I can identify the dialogue between characters in the story. & 4.29 & 1.888 \\
I can identify where the story happened. & 4.12 & 1.659 \\
\hline Average Score & $\mathbf{4 . 2 1}$ & $\mathbf{1 . 7 7 4}$ \\
\hline
\end{tabular}

Findings shown in Table 7 revealed learners strongly agreed $(\mathrm{M}=4.29$ and $\mathrm{SD}=1.888)$ they can identify dialogues between characters in the and also agreed $(\mathrm{M}=4.12$ and $\mathrm{SD}=1.659)$ they can identify where the study happened with ease. The findings show that. Average performance for brain writing strategy revealed $\mathrm{M}=4.21$ and std dev of 1.174 implying that teachers of English use of brain writing strategy highly contributes to learners composition writing skills. Similarly, Barr (2016) whose study on "brain-based learning and its effects on reading outcome in elementary aged students" is in agreement with the reported positive correlation between brain writing based learning strategies and expected student achievement for these students.

\section{Hypothesis Testing for Whole Group Technique}

This study sought to test the second Null Hypothesis $\left(\mathrm{HO}_{2}\right)$ which assumed no statistical significant relationship between whole group technique and learners' achievement in composition writing skills in public primary schools in Kisumu County. The result for Z-test statistics are shown in Table 4.28.

\begin{tabular}{lll}
\hline & Experiment Group & \\
\cline { 2 - 3 } Technique & z-Statistics & P-value \\
\hline Whole group technique & 8.23982 & 0.0012 \\
\hline
\end{tabular}

Results from Table 4.28 revealed that the whole group technique computed $\mathrm{z}$ statistic showed $\mathrm{z}=8.23982$ and $\mathrm{p}=0.0012$. The $\mathrm{p}$-value was less than the $0.05(\mathrm{p}<0.05)$ which is the bench mark value for rejecting the Null Hypothesis assuming 95\% significance level. Therefore, the study rejected that Null Hypothesis, as there was a statistically significant relationship between whole group technique and learners' achievement in composition writing skills in public primary schools in Kisumu County

\section{Conclusion}

The study concluded that brain writing strategy is moderately used in teaching composition writing in public primary schools and pie storm teaching technique is highly used in teaching composition in public primary schools. In addition, use of brain storming, brain wave, and brain writing strategies relatively contributes to learners' composition writing skills. The $p$-value was less than the $0.05(p<0.05)$ which is the bench mark value for rejecting the Null Hypothesis assuming 95\% significance level. Therefore, the study rejected that Null Hypothesis, as there was a statistically significant relationship between whole group technique and learners' achievement in composition writing skills in public primary schools in Kisumu County.

Thus, whole group technique positively influences learners' achievement in composition writing skills in public primary schools. Finally yet importantly, the use of brainstorming teaching technique increases pass rate by $33.5 \%$ thus learners' achievement.

\section{Recommendations}

Based on the findings and conclusions made by the study, the following recommendations are presented:

* Brain writing strategy need to be implemented to enhance the composition writing skills in public primary schools in Kenya.

* For policy makers and implementers, ministry of Education and Kenya National Examination Council, should address the use of inquiring-based learning in order to provoke critical-thinking in learners as the new (CBC) gets rooted to curb the negative attitude of embracing change of teaching for life and not for 
exams.

* For theory similar studies should be carried out using inferential statistics, especially multiple regression analysis to assess how the individual strategies of brainstorming teaching technique contribute to overall learners' learning achievements.

* Other researches can use the Humanist child development theory to cater for the concerns of a paradigm shift to the thinking about holistic development of the learners. .

\section{REFERENCES}

Al-maghawry, A. (2012). Effectiveness of Using the Brainstorming Technique to Learn Some Basic Skills and Collection of Knowledge for Beginners in Volleyball. World Journal of Sport Sciences 6 (4): 361-366

Almutairi (2015), The Effect of Using Brainstorming Strategy in Developing Creative Problem Solving Skills among male Students in Kuwait: A Field Study on Saud Al-Kharji School in Kuwait City Journal of Education and Practice ISSN 2222-1735 (Paper) ISSN 2222-288X (Online) Vol.6, No.3, 2015

Artini, Y. (2011), The effectiveness of the Brain Based Teaching Approach in generating students' learning motivation towards the subject of Physics: A Quantitative Approach. US-China, Education Review. A1. 6372. African Research Review, 5(3). doi:10.4314/afrrev.v5i3.67342

Barr, A. (1991), Descriptive study of reading strategies for secondary school education in Minnesota public schools. New York: Berkeley Books.

Cohen, L., Manion, L. \& Morrison, K. (2007).Research methods in education ( $6^{\text {th }}$ edn.).London: Routledge.

Hatties,J(2009) Visible learning : A Sythesis of over 800 metarAnalyses Relating to Achievements .Oxford Routledges.

Heiman, G. (1999). Research methods in psychology. Boston: Houghton Mifflin Company.

Hun and Chik (2018) The learning of mind mapping in higher Education: A Comparative Study Between Universidad de C'ordoba and Universita' di Roma - La Sapien za Published in the Russian Federation European Researcher Has been issued since 2010. ISSN 2219-8229 E-ISSN 2224-0136 Vol. 83, No. 9-2, pp. 1682-1693, 2014 DOI: 10.13187/er.2014.83.1682

Javadi, H (2013) Transcranial electrical brain stimulation modulates neuronal tuning curves in perception of numerosity and duration journal homepage: www.elsevier.com/locate/ynimg NeuroImage 102 (2014) 451457

Kenya National Examination Council, (2007-2013). Kenya Certificate of Secondary Examination.Nairobi: KNEC.

Khulaif, Alya \& Alshammari, Alya. (2016). Developing the English Curriculum in the Kingdom of Saudi Arabia: Possibilities and Challenges. SSRN Electronic Journal. 6. 365-372. 10.2139/ssrn.2847465

Kiedinger, Rhonda. (2011). Brain Based Learning and its effects on reading outcome in elementary aged students. Dissertation submitted to the Graduate School, University of Wisconsin-Stout.

Martal, A. (2014). The Role of Computer Assisted Language Learning (CALL) for English Language learning of Elementary and High Schools In Indonesia in Journal Register volume 5, No. 2.

Martin, L. (2013). Funds of Knowledge in the Primary Classroom: Establishing Relevance in the Social Studies Curriculum. IMPLEMENTING NEW STRATEGIES, 1(1), 29. Brain-Writing Vs. Brainstorming Case Study For Power Engineering Education

Marcela Litcanua*, Octavian Prosteana, Cosmin Orosa, Alin Vasile and Mnerieb (2014)Brain-Writing Vs. Brainstorming Case Study For Power Engineering Education a Politehnica University of Timisoara, Power Systems Department, 2 Bd. V, Parvan, 300223 Timisoara, Romania b "Ioan Slavici" University of Timisoara, 144 Dr. Aurel Paunescu Podeanu, 300587, Timisoara, Romania Procedia - Social and Behavioral Sciences 191 ( 2015 ) $387-390$

Mundu, J (2017) Integrating ICT into Teaching and Learning Biology: A Case for Rachuonyo South Sub-County, Kenya. American Journal of Education and Information Technologies 2017;1(2):1723http://www.sciencepublishinggroup.com/j/ajeit doi:10.11648/j.ajeit.20170102.12

Mwangi, L (2016) Effects of Dramatization on Learning of the English Language in Meru County, Kenya. Journal of Literature, Languages and Linguistics www.iiste.org ISSN 2422-8435 An International Peerreviewed Journal Vol.15, 2015

Orodho, J. Nzabaliwa, W. Odundo, P. Waweru, P. Ndayambaje, I (2016) .Quantitative and Qualitative Research Methods in Education and Social Sciences : A step by step Guide to scholarly Excellence First Edition June2016,@ Kanezja publishers \& Enter prises Nairobi, Kenya ISBN: 978-9966-7550-3-8.

Odu .G, O and Owab, O (2017) Development of Team-compromised Instrument for Group Decision-making using Modified Nominal Group Technique International Journal of Latest Research in Engineering and Technology (IJLRET) ISSN: 2454-5031 www.ijlret.com || Volume 03 - Issue 03 || March 2017 || PP. 35-46 www.ijlret.com 35 | Page

Westbye, (2012)."Don't worry Mr Trimble, we can handle it"; balancing the rational and emotional in the 
teaching of contentious topics'. Teaching History 106, Otizere and Communities Brain-Writing Vs. Brainstorming Case Study For Power Engineering Education

Marcela Litcanua*, Octavian Prosteana , Cosmin Orosa, Alin Vasile Mnerieb a Politehnica University of Timisoara, Power Systems Department, 2 Bd. V, Parvan, 300223 Timisoara, Romania b "Ioan Slavici" University of Timisoara, 144 Dr. Aurel Paunescu Podeanu, 300587, Timisoara, Romania 